\title{
Therapeutic strategies of melatonin in cancer patients: a systematic review and meta-analysis
}

This article was published in the following Dove Press journal:

OncoTargets and Therapy

\author{
Yi Wang* \\ Pengcheng Wang* \\ Xiaoli Zheng \\ Xing Du*
}

Department of Pharmacy, The Affiliated Yantai Yuhuangding Hospital of Qingdao University, Yantai, China

*These authors contributed equally to this work
Correspondence: Xing Du

Department of Pharmacy, The Affiliated Yantai Yuhuangding Hospital of Qingdao University, No. 20 Yudong Road, Yantai, Shandong 264000, China

Tel +86 I890535 I022

Email dxsj22@outlook.com
Background: Melatonin (MLT), a kind of neuroendocrine active substance, has been reported to function in the treatment of tumors. However, there remain controversies about the curative effect of MLT in tumors in clinical studies. This study investigates the efficacy of MLT on tumor therapeutic strategies by meta-analysis.

Methods: After searching several main literature databases, a total of 5,057 articles were obtained and screened by inclusion and exclusion criteria. The tumor remission rate, overall survival rate, and incidence of side effects were recorded and analyzed in the included study patients. Group analysis and sensitivity analysis were performed to examine the sources of heterogeneity in the pooled studies.

Results: The tumor remission rate in the MLT group was significantly higher than that in the control group (relative risk $[\mathrm{RR}]=2.25 ; 95 \% \mathrm{CI}, 1.86-2.71 ; P<0.00001 ; I^{2}=9 \%$ ). Likewise, the MLT group had an overall survival rate of $28.24 \%(\mathrm{n}=294 / 1,041)$, which was greatly increased compared with the control group ( $\mathrm{RR}=2.07 ; 95 \% \mathrm{CI}, 1.55-2.76 ; P<0.00001 ; I^{2}=55 \%$ ). And, MLT could significantly enhance the overall survival rate in non-small-cell lung cancer patients $\left(\mathrm{RR}=2.13 ; 95 \% \mathrm{CI}, 1.41-3.24 ; P=0.0004 ; I^{2}=0 \%\right)$ and various solid tumor patients $(\mathrm{RR}=2.31$; 95\% CI, $1.78-2.99 ; P<0.00001 ; I^{2}=0 \%$ ). It was further proved that MLT could effectively reduce the incidence of neurotoxicity $(\mathrm{RR}=0.30,95 \% \mathrm{CI}, 0.19-0.45 ; P<0.00001)$, thrombocytopenia $(\mathrm{RR}=0.23 ; 95 \% \mathrm{CI}, 0.16-0.33 ; P<0.00001)$, and asthenia $(\mathrm{RR}=0.43,95 \% \mathrm{CI}, 0.38-0.49$; $P<0.00001$ ) during chemotherapy.

Conclusion: MLT exerts positive influence in tumor therapeutic strategies, including improving tumor remission rate and overall survival rate, while reducing the incidence of chemotherapy side effects. Further large-scale randomized clinical trials (RCTs) are urgently required to verify therapeutic effects of MLT in tumors by various clinical research centers.

Keywords: MLT, tumor remission rate, overall survival rate, side effects of chemotherapy

\section{Introduction}

Melatonin (MLT) is a kind of neuroendocrine active substance, a steroid hormone, chemically composed of $N$-acetyl-5-methoxytryptamine, which synthesized and secreted by the pineal gland. ${ }^{1}$ MLT not only involves regulating biological rhythms and endocrine function but also functions in the occurrence, development, and treatment of cancer. ${ }^{2}$ Under physiological conditions, the level of MLT in the human body fluctuates within a certain range, with obvious circadian rhythm, which is the highest ${ }^{3}$ at night and the lowest at noon. ${ }^{4}$ However, in tumor circumstances, endogenous MLT has lost circadian rhythm and the level of MLT in cancer patients is abnormal. ${ }^{5-7}$

Preclinical experimental studies in recent years have shown that MLT has significant effects in preventing, treating, and delaying tumor development. Animal study demonstrates that the growth and proliferation of the tumors were accelerated after 
the pinealectomy. ${ }^{8,9}$ Further studies evidence that exogenous MLT exerted a certain degree of inhibition on the growth of tumors. ${ }^{10}$ Because of containing lipophilic groups, MLT has the ability to quickly pass through the cell membrane and nuclear membrane. Also, there are MLT high-affinity receptors in the cell membrane of various tissue cells, ${ }^{11}$ providing a physiological basis for its direct function. Preclinical studies reveals that MLT functions in anticancer effects mainly through the following ways: ${ }^{2,12} 1$ ) by binding to MLT membrane receptors, MLT could exert antiangiogenic effects in tumor (such as neuroblastoma and ovarian carcinoma) by the downregulation of vascular endothelial growth factor (VEGF); ${ }^{13,14}$ 2) MLT has the ability to inhibit the growth of breast cancer through interference with estrogen sulfatase enzyme; ${ }^{15}$ 3) MLT could function as immunomodulatory effect by regulating mononuclear cells to induce tumor cell apoptosis and arrest tumor cell cycle in $\mathrm{G}_{0} / \mathrm{G}_{1},{ }^{16} 4$ ) MLT could suppress the metastasis of triple-negative breast cancer by inducing KISS1 expression; ${ }^{17}$ 5) MLT would decrease epithelial-mesenchymal transition (EMT) and matrix metalloproteinase 9 (MMP9) activity to control the invasion and metastasis of cancer stem cells; ${ }^{18}$ 6) MLT is able to reduce prostate cancer cell growth and promote neuroendocrine differentiation via binding MLT membrane receptors, ${ }^{19}$ 7) MLT could potentiate the antitumor effect and overcome the resistance of chemotherapy, radiotherapy and other therapy. ${ }^{20-22}$

MLT can significantly inhibit the proliferation of cancer cells, a discovery that pioneered MLT antitumor research. ${ }^{23,24}$ Modern biomedical research shows that MLT receptors and related signal transduction pathways have a close relationship with the proliferation, differentiation, and apoptosis of cancer. ${ }^{25}$ Unfortunately, clinical studies have not unified opinions on the therapeutic effect of MLT in tumors. In most randomized clinical trials (RCTs), it is believed that supplement of MLT could enhance tumor remission response and survival rates, ${ }^{26,27}$ while reducing the incidence of side effects in chemotherapy or radiotherapy. However, considering the study of Sookprasert et al, ${ }^{28}$ it was not found that MLT can affect the survival rate and incidence of side effects in patients with non-small-cell lung cancer. In this study, a systematic review and metaanalysis of the literature for all RCTs was performed to verify tumor remission, survival rate, and therapy-related side effects involving the use of MLT in the treatment of various cancers.

\section{Methods}

\section{Inclusion and exclusion criteria}

\section{Inclusion criteria}

1) The study was designed as a randomized controlled trial. 2) The study subjects were any type of cancer patients who were diagnosed by histological section, regardless of age, gender, and tumor stage. 3) The intervention group included MLT combined with other treatments (including chemotherapy, molecular targeted therapy, radiotherapy, and supportive therapy). The control group received only other treatments (including chemotherapy, molecular targeted therapy, radiotherapy, and supportive therapy). 4) Outcome indexes include at least one of the following three indicators: disease remission rate, overall survival rate, and incidence rate of adverse reactions. There are four outcomes after the use of antitumor drugs: complete remission (CR), partial remission $(\mathrm{PR})$, stable disease $(\mathrm{SD})$, and disease progression (PD). According to the WHO criteria, in CR, all tumor damages completely disappeared at least 1 month, in PR, the sum of the two longest diameters of tumor reduced by more than $50 \%$ for at least 1 month, SD, the sum of the two longest diameters of tumor reduced by more than $25 \%$, or no tumor lesion, and in PD, the tumor damage increased by more than $25 \%$ or the appearance of new lesions. CR rate with $\mathrm{PR}$ rate equals disease remission rate.

\section{Exclusion criteria}

Animal studies, secondary literature studies, pharmacokinetic studies, nonrandomized controlled trials, and interventions such as non-MLT were excluded.

\section{Search strategy}

Using MLT, neoplasm/neoplasms, tumor/tumors, and cancer as search terms, the databases such as Web of Science, PubMed, China National Knowledge Infrastructure (CNKI), and Cochrane Database of Systematic Reviews were searched. The publication time was unlimited. Languages were limited to Chinese and English.

According to PRISMA's (preferred reporting items for systematic reviews and meta-analyses's) procedure for literature screening. ${ }^{29}$ Two investigators independently conducted data extraction and used the modified Jadad scoring standard ${ }^{30}$ to score the quality of the included studies (1-3 were classified as low-quality literature and 4-7 were classified as highquality literature) and then cross-checked. If there were any differences, it would be resolved through discussion.

\section{Data extraction}

After careful reading of the included literature, the following data were extracted and summarized: author, time of publication, types of tumor, number of cases, age, interventions, dosage, outcome indexes (rate of disease remission, overall survival rate, and rate of adverse reactions), and conclusions. 


\section{Statistical methods}

Meta-analysis is performed using the Review Manager 5.3 software. Relative risk (RR) and its 95\% CI are adopted to analyze therapeutic efficacy, which belongs to two-category variables. First, the heterogeneity test was performed on the included studies. When the heterogeneity test results showed no statistical heterogeneity among the test results $(P>0.10)$, a fixed effect model was used for meta-analysis; otherwise, a random effect model was selected for analysis. Funnel plot was performed with R packages (meta) and tested by Harbord test.

\section{Results}

\section{Characteristics of studies and data}

After searching the Web of Science, PubMed, CNKI, and Cochrane Database of Systematic Reviews, 4,881 articles were obtained and 12 articles were acquired by tracking citation. A total of 2,138 studies were removed by duplicates. After reading titles, abstracts, and keywords, there remained 107 records for further check. Screening review articles and experimental studies (77 articles), excluding non-RCT literature (10 articles), the final 20 literatures were included in the study. Figure 1 represents the literature screening process and results. The basic information of the included studies is shown in Table 1. The span of publication time of the literature was 1992-2014, relatively concentrated between 1994 and 2002. There were 3,853 cancer patients in the literature, involving multiple tumors (13 literatures for lung cancer, 11 literatures for digestive system tumors, seven literatures for breast cancer, two literatures for prostate cancer, two literatures for renal cancer, one literature for head and neck
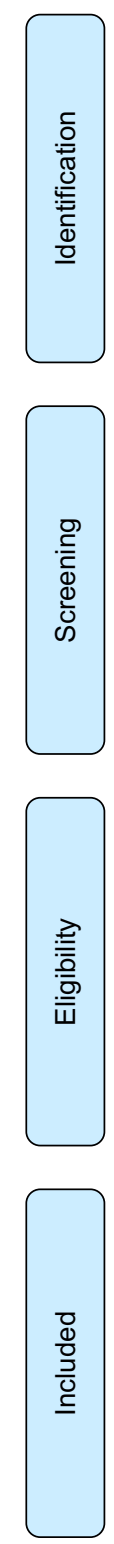

Records identified through database searching $(n=4,881)$
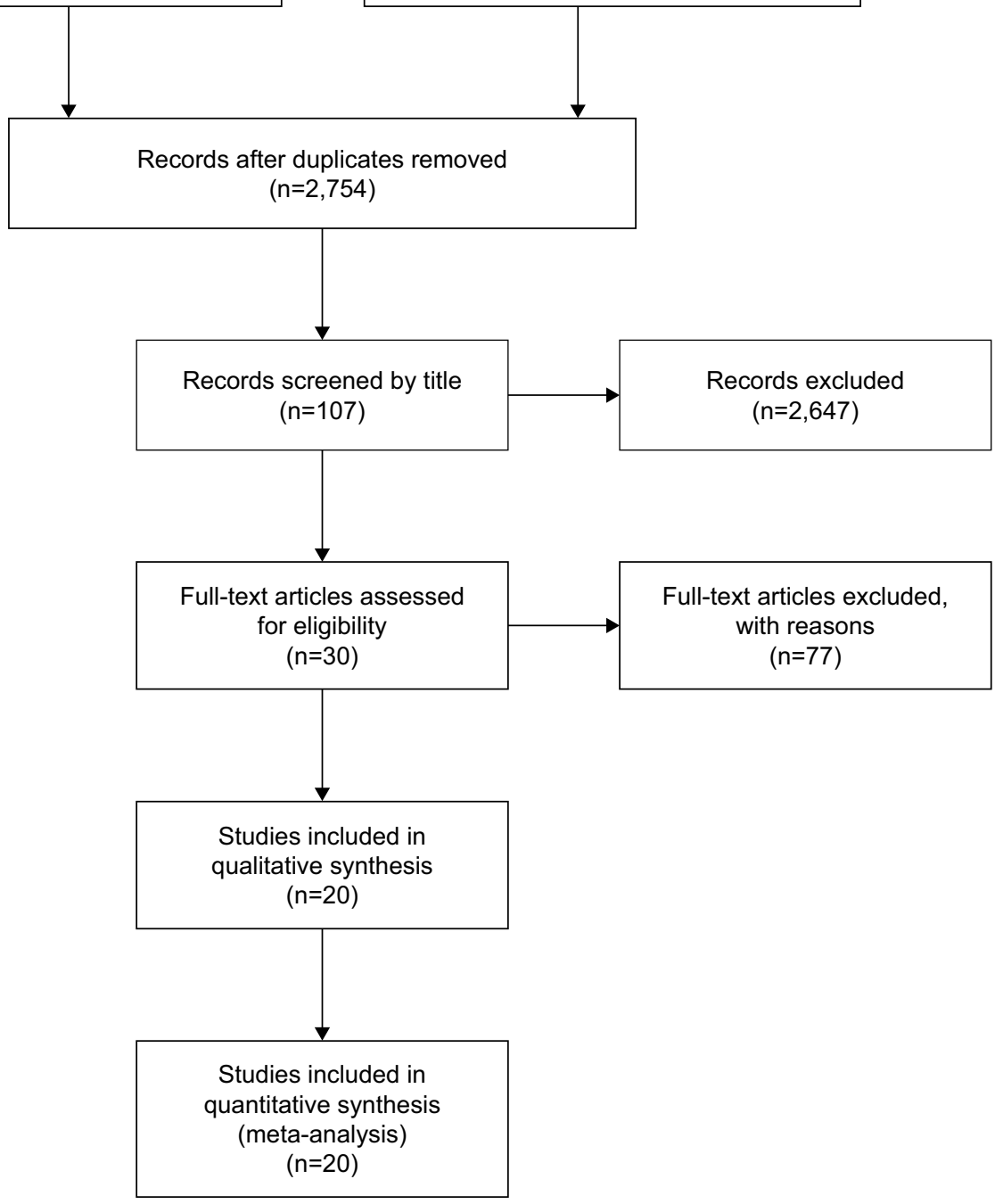

Figure I The flow chart of the literature screening process. 
Table I Characteristics of the included studies

\begin{tabular}{|c|c|c|c|c|c|c|}
\hline Articles & Types of tumor & $\begin{array}{l}\text { Case number } \\
\text { (T/C) }\end{array}$ & $\begin{array}{l}\text { Age } \\
\text { range }\end{array}$ & Interventions & Dosage & CR (T vs C) \\
\hline $\begin{array}{l}\text { Sookprasert } \\
\text { et al }(2014)^{28}\end{array}$ & Advanced NSCLC & $104 / 47$ & $18-70$ & $\begin{array}{l}\text { MLT + chemotherapy vs } \\
\text { placebo + chemotherapy }\end{array}$ & $\begin{array}{l}10 \text { or } 20 \mathrm{mg} / \text { day orally } \\
\text { at night }\end{array}$ & - \\
\hline $\begin{array}{l}\text { Lissoni et al } \\
(2008)^{35}\end{array}$ & $\begin{array}{l}\text { Metastatic solid tumor } \\
\text { (NSCLC or gastrointestinal } \\
\text { tract tumors) }\end{array}$ & $285 / 286$ & $45-78$ & $\begin{array}{l}\text { MLT + supportive care vs } \\
\text { supportive care }\end{array}$ & $\begin{array}{l}20 \mathrm{mg} / \text { day orally in the } \\
\text { evening }\end{array}$ & $0 / 285$ vs $0 / 286$ \\
\hline Lissoni $(2007)^{36}$ & Metastatic NSCLC & $35 / 33$ & $49-73$ & $\begin{array}{l}\text { MLT + chemotherapy vs } \\
\text { chemotherapy alone }\end{array}$ & $\begin{array}{l}20 \mathrm{mg} / \text { day orally during } \\
\text { the dark period of the } \\
\text { day }\end{array}$ & $1 / 33$ vs $0 / 35$ \\
\hline Lissoni $(2007)^{37}$ & $\begin{array}{l}\text { Metastatic solid tumor } \\
\text { (NSCLC or gastrointestinal } \\
\text { tract tumors) }\end{array}$ & $187 / 183$ & - & $\begin{array}{l}\text { MLT + chemotherapy vs } \\
\text { chemotherapy alone }\end{array}$ & $\begin{array}{l}20 \mathrm{mg} / \text { day orally in the } \\
\text { evening }\end{array}$ & $12 / 187$ vs $5 / 183$ \\
\hline $\begin{array}{l}\text { Lissoni et al } \\
(2003)^{38}\end{array}$ & Metastatic NSCLC & $49 / 51$ & $38-81$ & $\begin{array}{l}\text { MLT + chemotherapy vs } \\
\text { chemotherapy alone }\end{array}$ & $\begin{array}{l}20 \mathrm{mg} / \text { day orally in the } \\
\text { evening }\end{array}$ & $2 / 49$ vs $0 / 51$ \\
\hline $\begin{array}{l}\text { Cerea et al } \\
(2003)^{39}\end{array}$ & Metastatic colorectal cancer & $14 / 16$ & $37-82$ & $\begin{array}{l}\text { MLT + irinotecan vs } \\
\text { irinotecan alone }\end{array}$ & $\begin{array}{l}20 \mathrm{mg} / \text { day orally in the } \\
\text { evening }\end{array}$ & - \\
\hline Lissoni $(2002)^{40}$ & $\begin{array}{l}\text { Advanced solid } \\
\text { tumor (including lung, } \\
\text { gastrointestinal, breast, } \\
\text { and prostate cancers) }\end{array}$ & $722 / 718$ & $36-86$ & $\begin{array}{l}\text { MLT + supportive care vs } \\
\text { supportive care }\end{array}$ & $\begin{array}{l}\text { Orally at } 20 \mathrm{mg} / \text { day } \\
\text { during the evening }\end{array}$ & - \\
\hline Lissoni $(2002)^{40}$ & $\begin{array}{l}\text { Advanced solid } \\
\text { tumor (including lung, } \\
\text { gastrointestinal, breast, and } \\
\text { prostate cancers) }\end{array}$ & $98 / 102$ & $36-75$ & $\begin{array}{l}\text { MLT + chemotherapy vs } \\
\text { chemotherapy alone }\end{array}$ & $\begin{array}{l}\text { Orally at } 20 \mathrm{mg} / \text { day } \\
\text { during the evening }\end{array}$ & $3 / 98$ vs $0 / 102$ \\
\hline $\begin{array}{l}\text { Yan et al } \\
(200 \mathrm{I})^{41}\end{array}$ & Advanced liver cancer & $70 / 70$ & $29-78$ & $\begin{array}{l}\text { MLT + TACE vs TACE } \\
\text { alone }\end{array}$ & $\begin{array}{l}\text { Orally at } 20 \mathrm{mg} / \mathrm{day} \\
\text { during the evening }\end{array}$ & $0 / 70$ vs $0 / 70$ \\
\hline
\end{tabular}




\begin{tabular}{|c|c|c|c|}
\hline $\begin{array}{l}\text { CR }+P R \\
(T \text { vs } C)\end{array}$ & $\begin{array}{l}\text { Survival } \\
\text { rate }\end{array}$ & Adverse effect: $T$ vs $C$ & Conclusions \\
\hline- & $\begin{array}{l}\text { I year: } \\
\text { 18/104 vs } \\
6 / 47\end{array}$ & $\begin{array}{l}\text { Fatigue: } 89 / 100 \text { vs } 39 / 45 \\
\text { Anorexia: } 82 / 100 \text { vs } 3 I / 45 \\
\text { Neuropathy: } 62 / 99 \text { vs } 3 I / 46 \\
\text { Anemia: } 48 / 102 \text { vs } 26 / 46 \\
\text { Nausea: } 4 I / 10 I \text { vs } 18 / 45 \\
\text { Liver dysfunction: } 2 I / I 0 I \text { vs } 13 / 46 \\
\text { Mucositis: } 24 / I 00 \text { vs } 10 / 45 \\
\text { Low glomerular filtration rate: } 12 / 102 \text { vs } 7 / 46 \\
\text { Febrile neutropenia: } 7 / 98 \text { vs } 3 / 42 \\
\text { Thrombocytopenia: } 4 / 100 \text { vs } 2 / 46\end{array}$ & $\begin{array}{l}\text { MLT in combination with chemotherapy did not affect survival and } \\
\text { adverse events of advanced patients with NSCLC }\end{array}$ \\
\hline $\begin{array}{l}10 / 285 \text { vs } \\
0 / 286\end{array}$ & $\begin{array}{l}2 \text { years: } \\
6 / 285 \text { vs } \\
0 / 286\end{array}$ & - & $\begin{array}{l}\text { The MLT alone was able to induce a significant increase of disease } \\
\text { stabilization and survival time with respect to supportive care alone }\end{array}$ \\
\hline $\begin{array}{l}13 / 33 \text { vs } \\
6 / 35\end{array}$ & - & $\begin{array}{l}\text { Thrombocytopenia: } 1 / 33 \text { vs } 7 / 35 \\
\text { Neurotoxicity: } 2 / 33 \text { vs } 8 / 25 \\
\text { Asthenia: } 4 / 33 \text { vs } 14 / 35\end{array}$ & $\begin{array}{l}\text { The overall response rate achieved in patients concomitantly treated } \\
\text { with MLT was significantly higher with respect to that obtained in } \\
\text { patients treated with chemotherapy alone. Moreover, MLT significantly } \\
\text { reduced some chemotherapy-related toxicities, thrombocytopenia, and } \\
\text { neurotoxicity }\end{array}$ \\
\hline $\begin{array}{l}68 / 187 \text { vs } \\
37 / 183\end{array}$ & $\begin{array}{l}2 \text { years: } \\
47 / 187 \text { vs } \\
24 / 183\end{array}$ & $\begin{array}{l}\text { Thrombocytopenia: } 8 / 187 \text { vs } 4 / / / 83 \\
\text { Neurotoxicity: } 10 / 187 \text { vs } 22 / / 83 \\
\text { Asthenia: } 51 / / 87 \text { vs } 96 / / 83 \\
\text { Neoplastic cachexia: } 9 / 187 \text { vs } 36 / 183\end{array}$ & $\begin{array}{l}\text { The response rate was greater in patients concomitantly treated } \\
\text { with } M L T \text { than in the group of chemotherapy alone for the overall } \\
\text { chemotherapies } \\
\text { The percentage of } 2 \text {-year survival achieved in patients concomitantly } \\
\text { treated with MLT was higher than that in those treated with } \\
\text { chemotherapy alone } \\
\text { Chemotherapy was better tolerated in patients concomitantly treated } \\
\text { with MLT }\end{array}$ \\
\hline $\begin{array}{l}17 / 49 \text { vs } \\
9 / 51\end{array}$ & $\begin{array}{l}\text { I year: } 20 / 49 \\
\text { vs } 10 / 5 \text { I } \\
5 \text { years: } 3 / 49 \\
\text { vs } 0 / 5 \text { I }\end{array}$ & $\begin{array}{l}\text { Neurotoxicity: } 2 / 49 \text { vs } 9 / 5 \text { । } \\
\text { Thrombocytopenia: } \mid / 49 \text { vs } 7 / 5 \text { | } \\
\text { Weight loss greater than } 10 \%: 3 / 49 \text { vs } 21 / 5 \text { I } \\
\text { Asthenia: } 4 / 49 \text { vs } 18 / 5 \text { I } \\
\text { Alopecia: } 14 / 5 \text { । vs } 1 \mid / 49 \\
\text { Anemia: } 6 / 5 \text { । vs } 4 / 49\end{array}$ & $\begin{array}{l}\text { Both the overall tumor regression rate and the } 5 \text {-year survival results } \\
\text { were significantly higher in patients concomitantly treated with MLT } \\
\text { This study confirms, in a considerable number of patients and for } \\
\text { a long follow-up period, the possibility to improve the efficacy } \\
\text { of chemotherapy in terms of both survival and quality of life by a } \\
\text { concomitant administration of MLT }\end{array}$ \\
\hline $\begin{array}{l}5 / 14 \text { vs } \\
2 / 16\end{array}$ & - & Diarrhea: $4 / 14$ vs $6 / 16$ & $\begin{array}{l}\text { The efficacy of weekly low-dose irinotecan (CPT-II) in pretreated } \\
\text { metastatic colorectal cancer patients may be enhanced by a concomitant } \\
\text { daily administration of the pineal hormone MLT }\end{array}$ \\
\hline $\begin{array}{l}17 / 722 \text { vs } \\
0 / 718\end{array}$ & - & $\begin{array}{l}\text { Cachexia: } 37 / 722 \text { vs } 189 / 718 \\
\text { Asthenia: } 126 / 722 \text { vs } 292 / 718 \\
\text { Anorexia: } 149 / 722 \text { vs } 226 / 7 \mid 8 \\
\text { Depressive symptoms: } 96 / 722 \text { vs } 164 / 7 \mid 8 \\
\text { Anemia: } 186 / 722 \text { vs } 218 / 718 \\
\text { Thrombocytopenia: } 21 / 722 \text { vs } 78 / 718 \\
\text { Lymphocytopenia: } 204 / 722 \text { vs } 489 / 7 \mid 8\end{array}$ & $\begin{array}{l}\text { The percentage of patients with disease stabilization and the percentage } \\
\text { of I-year survival were significantly higher in patients concomitantly } \\
\text { treated with MLT than in those treated with supportive care alone }\end{array}$ \\
\hline $\begin{array}{l}32 / 98 \text { vs } \\
20 / 102\end{array}$ & - & $\begin{array}{l}\text { Asthenia: } 25 / 98 \text { vs } 46 / 102 \\
\text { Alopecia: } 62 / 98 \text { vs } 72 / 102 \\
\text { Vomiting: } 46 / 98 \text { vs } 56 / 102 \\
\text { Stomatitis: } 15 / 98 \text { vs } 36 / 102 \\
\text { Diarrhea: } 19 / 98 \text { vs } 24 / 102 \\
\text { Neurotoxicity: } 8 / 98 \text { vs } 26 / 102 \\
\text { Nephrotoxicity: } 0 / 98 \text { vs } 6 / 102 \\
\text { Cardiotoxicity: } 2 / 98 \text { vs } 9 / 102 \\
\text { Leukopenia: } 14 / 98 \text { vs } 18 / 102 \\
\text { Anemia: } \mid 2 / 98 \text { vs } 14 / 102 \\
\text { Thrombocytopenia: } 2 / 98 \text { vs } 17 / 102\end{array}$ & $\begin{array}{l}\text { The objective tumor response rate was significantly higher in patients } \\
\text { treated with chemotherapy plus MLT than in those treated with } \\
\text { chemotherapy alone. Moreover, MLT induced a significant decline in } \\
\text { the frequency of chemotherapy-induced asthenia, thrombocytopenia, } \\
\text { stomatitis, cardiotoxicity, and neurotoxicity }\end{array}$ \\
\hline $\begin{array}{l}16 / 70 \text { vs } \\
9 / 70\end{array}$ & $\begin{array}{l}\text { I year: } 48 / 70 \\
\text { vs } 38 / 70\end{array}$ & - & $\begin{array}{l}\text { Compared with the control group, the MLT group significantly increased } \\
\text { the tumor response and survival rate }\end{array}$ \\
\hline
\end{tabular}


Table I (Continued)

\begin{tabular}{|c|c|c|c|c|c|c|}
\hline Articles & Types of tumor & $\begin{array}{l}\text { Case number } \\
(\mathrm{T} / \mathrm{C})\end{array}$ & $\begin{array}{l}\text { Age } \\
\text { range }\end{array}$ & Interventions & Dosage & CR (T vs C) \\
\hline $\begin{array}{l}\text { Lissoni et al } \\
(2000)^{42}\end{array}$ & Metastatic renal cell cancer & $14 / 16$ & $28-63$ & $\begin{array}{l}\text { MLT + morphine + IL-2 vs } \\
\text { MLT + morphine }\end{array}$ & $\begin{array}{l}20 \mathrm{mg} / \text { day during the } \\
\text { evening }\end{array}$ & $0 / 14$ vs $0 / 16$ \\
\hline $\begin{array}{l}\text { Lissoni et al } \\
(1999)^{43}\end{array}$ & $\begin{array}{l}\text { Metastatic solid } \\
\text { tumor (including lung, } \\
\text { gastrointestinal, breast, and } \\
\text { head and neck cancers) }\end{array}$ & $124 / 126$ & $39-81$ & $\begin{array}{l}\text { MLT + chemotherapy vs } \\
\text { chemotherapy alone }\end{array}$ & $\begin{array}{l}\text { Orally at } 20 \mathrm{mg} / \text { day } \\
\text { during the evening }\end{array}$ & $6 / 124$ vs $0 / 126$ \\
\hline $\begin{array}{l}\text { Lissoni et al } \\
(1997)^{44}\end{array}$ & $\begin{array}{l}\text { Metastatic solid } \\
\text { tumors (including lung, } \\
\text { gastrointestinal, and breast } \\
\text { cancer) }\end{array}$ & $39 / 41$ & $38-76$ & $\begin{array}{l}\text { MLT + chemotherapy vs } \\
\text { chemotherapy alone }\end{array}$ & $\begin{array}{l}\text { Orally at } 20 \mathrm{mg} / \text { day } \\
\text { during the evening }\end{array}$ & $1 / 39$ vs $0 / 4 \mid$ \\
\hline $\begin{array}{l}\text { Lissoni et al } \\
(1997)^{45}\end{array}$ & Advanced NSCLC & $34 / 36$ & $39-80$ & $\begin{array}{l}\text { MLT + chemotherapy vs } \\
\text { chemotherapy alone }\end{array}$ & $\begin{array}{l}\text { Orally at } 20 \mathrm{mg} / \text { day } \\
\text { during the evening }\end{array}$ & $1 / 34$ vs $0 / 36$ \\
\hline $\begin{array}{l}\text { Yan et al } \\
(1997)^{46}\end{array}$ & Advanced liver cancer & $31 / 29$ & $38-72$ & $\begin{array}{l}\text { MLT + supportive care vs } \\
\text { supportive care }\end{array}$ & $\begin{array}{l}\text { Orally at } 20 \mathrm{mg} / \text { day } \\
\text { during the evening }\end{array}$ & $0 / 31$ vs $0 / 29$ \\
\hline $\begin{array}{l}\text { Lissoni et al } \\
(1996)^{47}\end{array}$ & Brain glioblastoma & $14 / 16$ & $37-76$ & $\begin{array}{l}\text { MLT + radiotherapy vs } \\
\text { radiotherapy alone }\end{array}$ & $\begin{array}{l}\text { Orally at } 20 \mathrm{mg} / \text { day } \\
\text { during the evening }\end{array}$ & - \\
\hline $\begin{array}{l}\text { Lissoni et al } \\
(1996)^{48}\end{array}$ & Malignant melanoma & $14 / 16$ & $38-81$ & $\begin{array}{l}\text { MLT + supportive care vs } \\
\text { supportive care }\end{array}$ & $\begin{array}{l}\text { Orally at } 20 \mathrm{mg} / \text { day } \\
\text { during the evening }\end{array}$ & - \\
\hline $\begin{array}{l}\text { Lissoni et al } \\
(1995)^{49}\end{array}$ & Metastatic breast cancer & $19 / 2 \mid$ & - & $\begin{array}{l}\text { MLT + tamoxifen vs } \\
\text { tamoxifen }\end{array}$ & $\begin{array}{l}\text { Orally at } 20 \mathrm{mg} / \text { day } \\
\text { during the evening }\end{array}$ & $0 / 19$ vs $0 / 21$ \\
\hline $\begin{array}{l}\text { Lissoni et al } \\
(1994)^{50}\end{array}$ & $\begin{array}{l}\text { Advanced solid } \\
\text { tumor (including lung, } \\
\text { gastrointestinal, and breast } \\
\text { cancers) }\end{array}$ & $41 / 39$ & $36-74$ & $M L T+I L-2$ vs $M L T+I L-2$ & $\begin{array}{l}\text { Orally at } 20 \mathrm{mg} / \text { day } \\
\text { during the evening }\end{array}$ & $3 / 41$ vs $0 / 39$ \\
\hline $\begin{array}{l}\text { Lissoni et al } \\
(1994)^{51}\end{array}$ & $\begin{array}{l}\text { Cancer with brain metastasis } \\
\text { (including melanoma, lung, } \\
\text { breast, and colon cancers) }\end{array}$ & $24 / 26$ & $38-72$ & $\begin{array}{l}\text { MLT + supportive care vs } \\
\text { supportive care }\end{array}$ & $\begin{array}{l}\text { Orally at } 20 \mathrm{mg} / \text { day } \\
\text { during the evening }\end{array}$ & - \\
\hline $\begin{array}{l}\text { Lissoni et al } \\
(1992)^{34}\end{array}$ & Metastatic NSCLC & $31 / 32$ & $39-78$ & $\begin{array}{l}\text { MLT + supportive care vs } \\
\text { supportive care }\end{array}$ & $\begin{array}{l}\text { Orally at } 10 \mathrm{mg} / \text { day } \\
\text { during the evening }\end{array}$ & - \\
\hline
\end{tabular}

Abbreviations: CR, complete remission; MLT, melatonin; NSCLC, non-small-cell lung cancer; PR, partial remission; TACE, transcatheter artery chemoembolization; $\mathrm{T}$, treatment group; C, control group; ER, estrogen receptor; IL-2, interleukin 2. 


\begin{tabular}{|c|c|c|c|}
\hline $\begin{array}{l}\text { CR }+P R \\
(T \text { vs } C)\end{array}$ & $\begin{array}{l}\text { Survival } \\
\text { rate }\end{array}$ & Adverse effect: $T$ vs $C$ & Conclusions \\
\hline $\begin{array}{l}42 / 124 \text { vs } \\
19 / 126\end{array}$ & $\begin{array}{l}3 \text { years: } 3 / 14 \\
\text { vs } 0 / 16 \\
\text { I year: } \\
63 / 124 \text { vs } \\
29 / 126\end{array}$ & 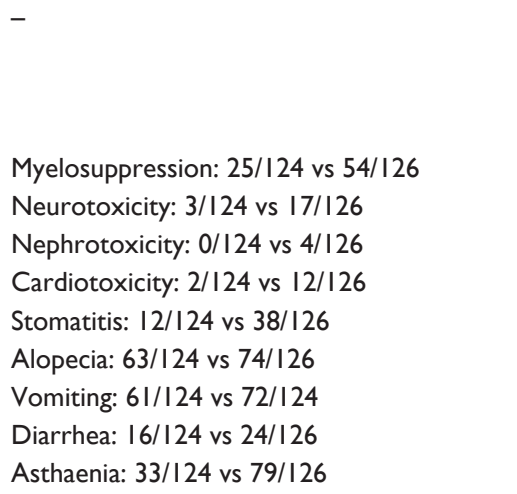 & $\begin{array}{l}\text { The percentage of partial responses achieved in patients treated with } \\
\text { morphine alone was significantly lower than that observed in patients } \\
\text { concomitantly treated with MLT. Moreover, the percentage of 3-year } \\
\text { survival was significantly higher in patients concomitantly treated with MLT } \\
\text { MLT may enhance the efficacy of chemotherapy and reduce its toxicity, } \\
\text { at least in advanced cancer patients of poor clinical status }\end{array}$ \\
\hline $\begin{array}{l}12 / 39 \text { vs } \\
9 / 41\end{array}$ & - & $\begin{array}{l}\text { Myelotoxicity: } 0 / 39 \text { vs } 8 / 4 \text { I } \\
\text { Stomatitis: } 2 / 39 \text { vs } 9 / 4 \text { I } \\
\text { Neuropathy grade I-2: } 0 / 39 \text { vs } 5 / 4 \text { I } \\
\text { Cardiac complications: } 0 / 39 \text { vs } 3 / 4 \text { I } \\
\text { Nephrotoxicity: } 0 / 39 \text { vs } I / 4 \text { I } \\
\text { Hepatotoxicity: } I / 39 \text { vs } 3 / 4 \text { I } \\
\text { Skin reactions: } 3 / 39 \text { vs } 3 / 4 \text { I } \\
\text { Alopecia grade I-3: } 7 / 39 \text { vs } 9 / 4 \text { I } \\
\text { Diarrhea grade I-2: } 3 / 39 \text { vs } 5 / 4 \text { I } \\
\text { Vomiting: II/39 vs } \mid 4 / 4 \text { I } \\
\text { Asthenia: } 4 / 39 \text { vs } 19 / 4 \mid\end{array}$ & $\begin{array}{l}\text { Concomitant administration of the pineal hormone MLT during } \\
\text { chemotherapy may prevent some chemotherapy-induced side effects, } \\
\text { particularly myelosuppression and neuropathy } \\
\text { Evaluation of the impact of MLT on chemotherapy efficacy will be the } \\
\text { aim of future clinical investigations }\end{array}$ \\
\hline $\begin{array}{l}11 / 34 \text { vs } \\
6 / 36\end{array}$ & $\begin{array}{l}\text { I year: } 15 / 34 \\
\text { vs } 6 / 36\end{array}$ & $\begin{array}{l}\text { Myelosuppression: } 4 / 34 \text { vs } 13 / 36 \\
\text { Vomiting: } 7 / 34 \text { vs } 10 / 36 \\
\text { Alopecia grade I-3: } 6 / 34 \text { vs } 9 / 36 \\
\text { Diarrhea grade } I-3: 1 / 34 \text { vs } 2 / 34 \\
\text { Neuropathy: } 0 / 34 \text { vs } 5 / 36 \\
\text { Nephropathy: } 0 / 34 \text { vs } 3 / 36 \\
\text { Asthenia: } 3 / 34 \text { vs } 12 / 36 \\
\text { Weight loss > }>\% \text { : } 0 / 34 \text { vs } 16 / 36\end{array}$ & $\begin{array}{l}\text { The concomitant administration of MLT may improve the efficacy } \\
\text { of chemotherapy, mainly in terms of survival time, and reduce } \\
\text { chemotherapeutic toxicity in advanced NSCLC, at least in patients in } \\
\text { poor clinical condition }\end{array}$ \\
\hline $\begin{array}{l}8 / 31 \text { vs } \\
1 / 29\end{array}$ & $\begin{array}{l}\text { I year: } 10 / 31 \\
\text { vs } 0 / 29\end{array}$ & - & $\begin{array}{l}\text { MLT may represent a new palliative therapy, capable of inducing tumor } \\
\text { regression, prolonging the survival time and improving the life quality of } \\
\text { patients with unresectable primary liver cancer }\end{array}$ \\
\hline $\begin{array}{l}6 / 11 \text { vs } \\
4 / 12\end{array}$ & $\begin{array}{l}\text { I year: } 6 / 14 \\
\text { vs } 1 / 16\end{array}$ & 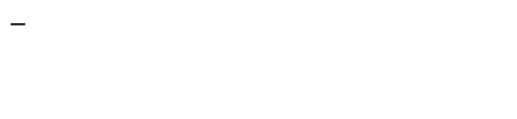 & $\begin{array}{l}\text { A radio neuroendocrine approach with radiotherapy plus MLT may } \\
\text { prolong the survival time and improve the quality of life of patients } \\
\text { affected by glioblastoma }\end{array}$ \\
\hline- & $\begin{array}{l}\text { I year: } 10 / 14 \\
\text { vs } 11 / 16\end{array}$ & - & $\begin{array}{l}\text { An adjuvant endocrine therapy with MLT may be effective in preventing } \\
\text { disease progression in node relapsed melanoma patients }\end{array}$ \\
\hline $\begin{array}{l}7 / 19 \text { vs } \\
2 / 21\end{array}$ & $\begin{array}{l}\text { I year: } 12 / 19 \\
\text { vs } 5 / 21\end{array}$ & No MLT-related toxicity was observed & $\begin{array}{l}\text { The pineal hormone MLT may make tamoxifen effective also in } \\
\text { ER-negative metastatic breast cancer patients }\end{array}$ \\
\hline $\begin{array}{l}\mathrm{I} \mid / 4 \mathrm{I} \text { vs } \\
\mathrm{I} / 39\end{array}$ & $\begin{array}{l}\text { I year: } 19 / 41 \\
\text { vs } 6 / 39\end{array}$ & $\begin{array}{l}\text { Fever: } 4 / 4 \text { I vs } 6 / 39 \\
\text { Vomiting: I/4I vs } 2 / 39 \\
\text { Anorexia: } 2 / 4 \text { I vs } 4 / 39 \\
\text { Asthenia: I/4I vs } 3 / 39 \\
\text { Arthralgia: } 0 / 4 \text { I vs } I / 39 \\
\text { Depressive symptoms: I/4I vs } 3 / 39 \\
\text { Transaminase increase: } 4 / 4 \text { I vs } 7 / 39 \\
\text { Anemia: I/4I vs } 2 / 39 \\
\text { Thrombocytopenia: } 0 / 4 \text { I vs } 3 / 39\end{array}$ & $\begin{array}{l}\text { The concomitant administration of the pineal hormone MLT may } \\
\text { increase the efficacy of low-dose IL-2 subcutaneous therapy }\end{array}$ \\
\hline- & $\begin{array}{l}\text { I year: } 9 / 24 \\
\text { vs } 3 / 26\end{array}$ & $\begin{array}{l}\text { Steroid-related infective complications: } 3 / 24 \\
\text { vs } 14 / 26\end{array}$ & $\begin{array}{l}\text { The pineal hormone MLT may be able to improve the survival time and } \\
\text { the quality of life in patients with brain metastases due to solid tumors }\end{array}$ \\
\hline- & $\begin{array}{l}\text { I year: } 8 / 3 \text { | } \\
\text { vs } 2 / 32\end{array}$ & - & $\begin{array}{l}\text { MLT may be successfully administered to prolong the survival time in } \\
\text { metastatic NSCLC patients who progressed under a first-line chemotherapy } \\
\text { with cisplatin, for whom no other effective therapy is available up to now }\end{array}$ \\
\hline
\end{tabular}


tumors, one literature for glioma, and two literatures for melanoma). The interventions were MLT combined with chemotherapy or other treatments as experimental group and chemotherapy or other treatments as control group. Among them, the dosage and the way of taking MLT are mostly $20 \mathrm{mg} /$ day and taken orally and taken at night, respectively. The MLT dosage was $10 \mathrm{mg} /$ day in the Lissoni 1992 study. The indicators for the studies were disease response rate (CR $+\mathrm{PR})$, overall survival rate, and incidence rate of side effects.

\section{Systematic review}

Through a systematic review of the literature, 20 original RCTs were included to conduct meta-analysis analysis. In addition, this study reviews other relevant literatures and systematic review literatures. The majority of cancer patients in these 20 primary RCTs were malignant metastatic solid tumors. Non-small-cell lung cancer was the most common type of cancer, followed by digestive system tumors. In most of the RCTs, it is believed that taking MLT can increase tumor remission response and survival rates, while reducing the incidence of side effects during chemotherapy or radiotherapy. However, in the study of Sookprasert 2014, it was not found that MLT could affect the survival rate and incidence of side effects in patients with non-small-cell lung cancer. A review of systematic review literatures demonstrated that the opinions on the tumorigenic effects of MLT are still inconsistent. A number of systematic studies have concluded that supplementation of MLT could increase the survival rate and disease remission rate in cancer patients, while reducing the incidence of side effects of radiotherapy and chemotherapy. Preclinical experimental research has confirmed that MLT was capable of scavenging ROS and repairing damaged DNA to exert antitumor effects. However, Vernieri et al pointed out that MLT is not recommended as an alternative treatment for cancer patients due to the lack of sufficient data to support the efficacy and safety of MLT in cancer treatment. ${ }^{52}$

\section{Meta-analysis}

\section{Tumor remission rate}

Among the 20 articles included, 16 studies were related to the disease response rate index, with CR of tumors or PR of tumors as the termination index. As shown in Figure 2, there was no heterogeneity among the results $\left(P=0.35, I^{2}=9 \%\right)$, so the results were combined using a fixed model. A total of 1,771 tumor patients were involved in the combined MLT group, and 279 of these patients had complete tumor remission or partial tumor remission, with a pooled tumor

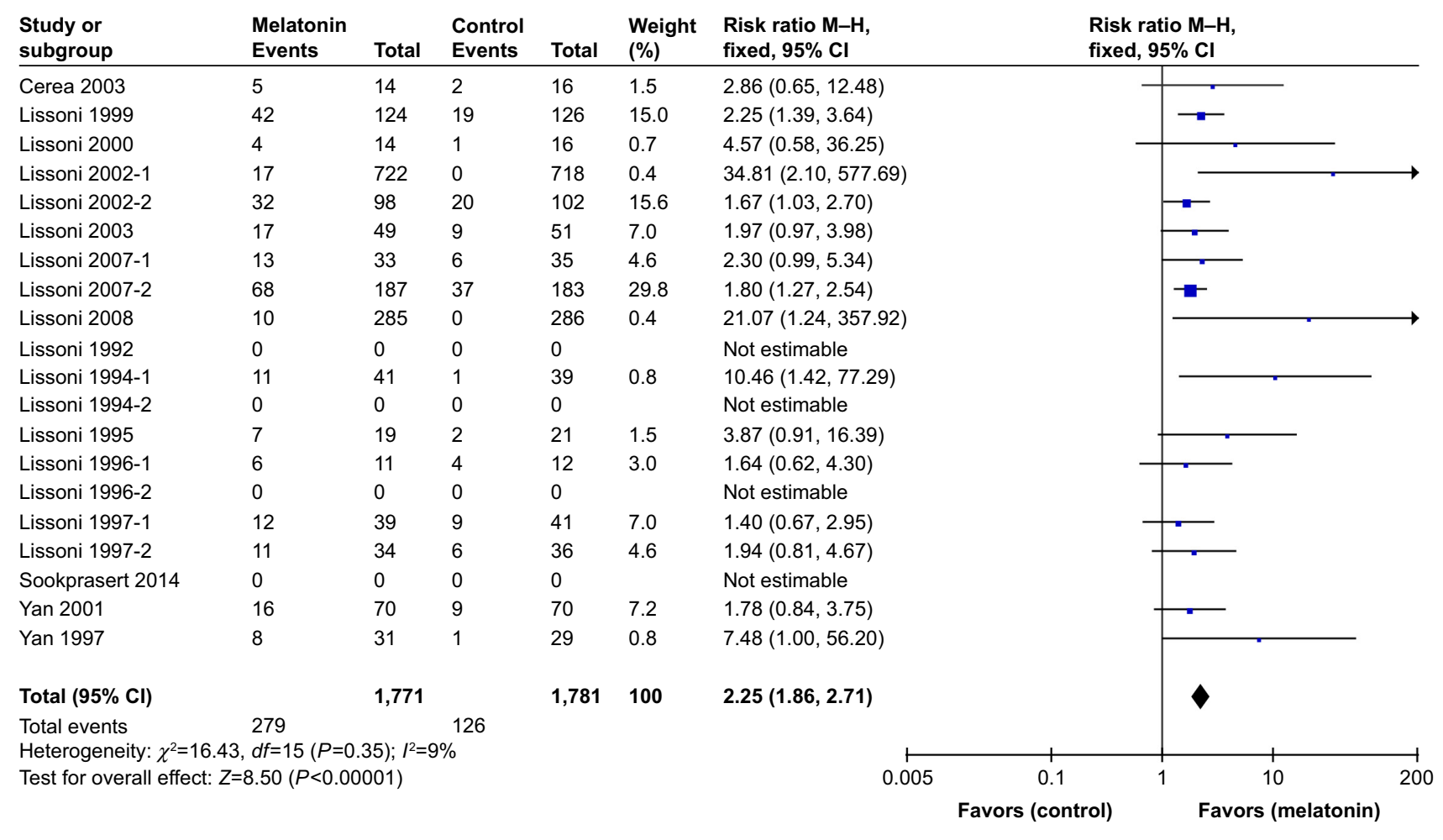

Figure 2 Meta-analysis of the tumor remission rate of cancer treated with MLT. Abbreviations: MLT, melatonin; M-H, Mantel-Haenszel. 
remission rate of $15.75 \%$. The control group had 1,781 cancer patients, of whom 126 patients developed complete tumor remission or partial tumor remission. The overall tumor remission rate was $7.07 \%$. MLT significantly increased the tumor remission rate compared to the control group $(\mathrm{RR}=2.25 ; 95 \% \mathrm{CI}, 1.86-2.71 ; P<0.00001)$.

\section{Overall survival rate}

There were 15 RCTs involved with the index of overall survival rate among the 20 studies included. The heterogeneity of these 15 researches was statistically different $(P=0.006$, $I^{2}=55 \%$ ), so a random model was adopted to combine the results (Figure 3). The overall survival rate in combined MLT group was 28.24\% ( $n=294 / 1,041)$, while the control group had an overall survival rate of $14.19 \%(n=141 / 994)$. Compared to the control group, MLT significantly increased the overall survival rate of cancer patients $(\mathrm{RR}=2.07 ; 95 \% \mathrm{CI}$, $1.55-2.76 ; P<0.00001)$. There was heterogeneity in various studies included; thus, we conducted sensitive analysis and stratified analysis to discuss the sources of heterogeneity. It could be seen that no single study had a great impact on the heterogeneity of the pooled results from sensitive analysis results. Stratified analysis was performed according to tumor types, and the heterogeneity of the combined study results was significantly reduced by stratified analysis. There were four RCTs studying patients with non-small-cell lung cancer in Figure 4, and there was no heterogeneity between the results $\left(P=0.55, I^{2}=0 \%\right)$. A total of 384 patients were involved in lung cancer; the survival rate of MLT group was $27.98 \%(n=61 / 218)$, which was significantly higher than that of $14.46 \%(n=24 / 166)$ in the control group. The pooled RR was 2.13 (95\% CI, 1.41-3.24; $P=0.0004)$. There were five clinical studies related to a variety of solid tumors in Figure 5. There was no heterogeneity in these results $\left(P=0.58, I^{2}=0 \%\right)$. There were a total of 1,321 cancer patients, of whom 661 patients were treated with MLT. And, in the MLT group, the survival rate was $21.79 \%(n=144 / 661)$, which was significantly higher than that of $9.39 \%(n=62 / 660)$ in the control group. The combined RR was 2.31 (95\% CI, $1.78-2.99 ; P<0.00001)$.

\section{Adverse effect rate}

The common side effects of radiotherapy and chemotherapy are neurotoxicity, thrombocytopenia, asthenia, alopecia, and oral mucositis. As an antioxidant, MLT can effectively scavenge free radicals generated during radiotherapy and chemotherapy to reduce the side effects. In the 20 randomized trials included, MLT was beneficial to reduce multiple side effects of radiotherapy and chemotherapy. Neurotoxicity, thrombocytopenia, and asthenia were studied more frequently $(>6)$. Therefore, data related to the incidence of neurotoxicity, thrombocytopenia, and asthenia were extracted and analyzed.

\section{Neurotoxicity}

A total of eight RCTs related to neurotoxicity are included in Figure 6 . There was a significant difference in heterogeneity

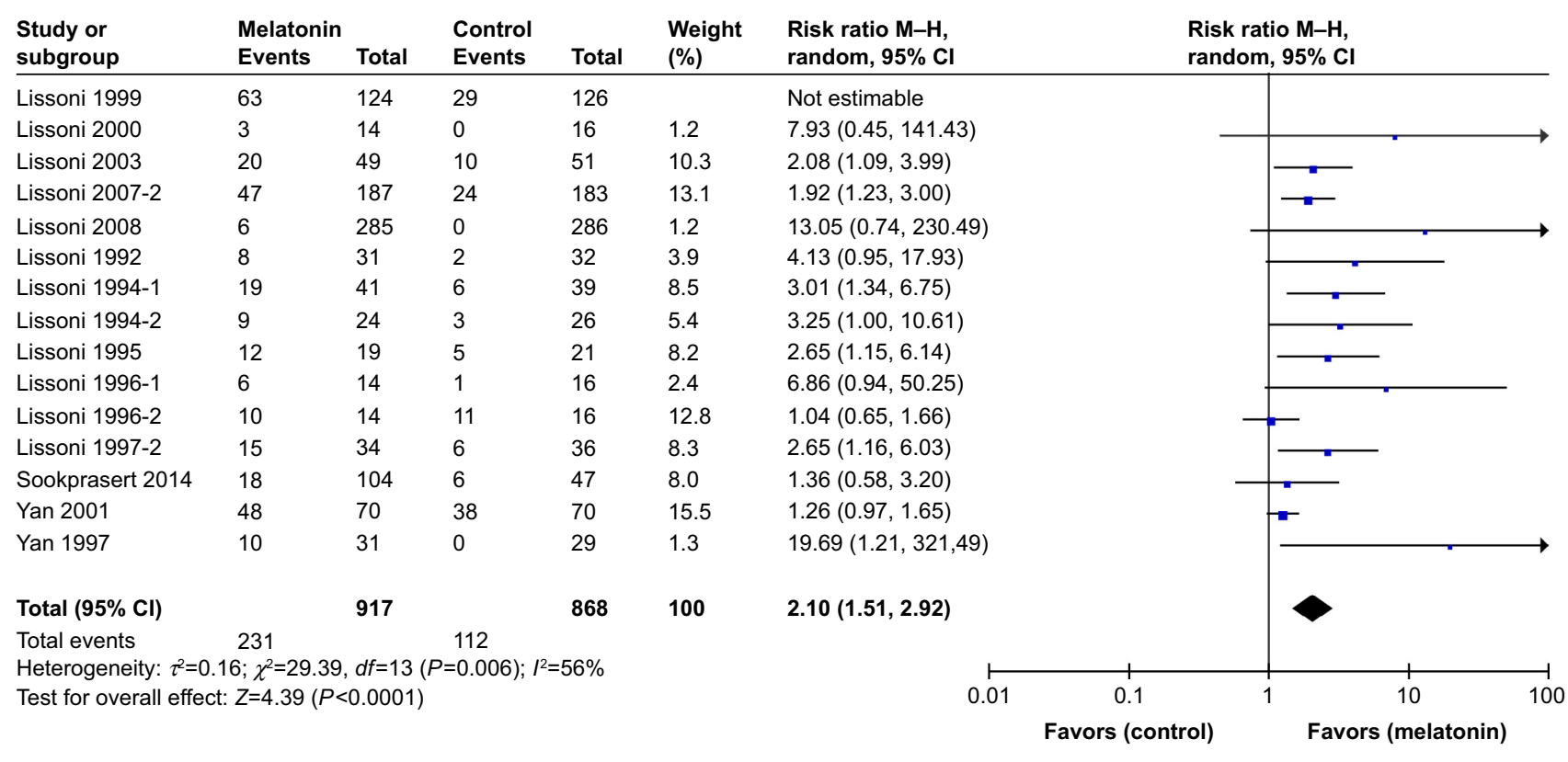

Figure 3 Meta-analysis of the overall survival rate of cancer treated with MLT. Abbreviations: MLT, melatonin; $\mathrm{M}-\mathrm{H}$, Mantel-Haenszel. 


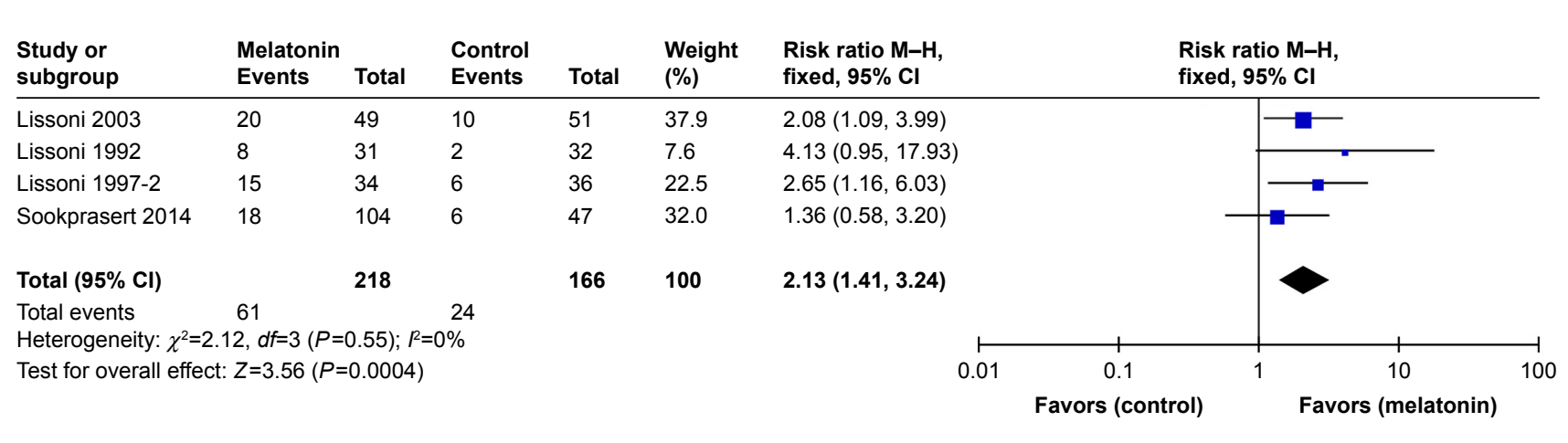

Figure 4 Meta-analysis of the overall survival rate of lung cancer treated with MLT. Abbreviations: MLT, melatonin; M-H, Mantel-Haenszel.

among the results $\left(I^{2}=80 \%\right)$, so the random model was applied to analyze the pooled data. The neurotoxicity rate in the MLT group was $13.12 \%(\mathrm{n}=87 / 663)$, which was significantly lower than that of $20.16 \%(n=123 / 610)$ in the control group $(\mathrm{RR}=0.31 ; 95 \% \mathrm{CI}, 0.14-0.66 ; P=0.003)$. The studies included were heterogeneous, and we conducted sensitive analysis to seek the sources of heterogeneity. The sensitivity analysis result found that the study of Sookprasert 2014 had a greater impact on the heterogeneity of the combined results (Figure 7). After removing the research of Sookprasert 2014, there was no heterogeneity between the results $(P=0.72$, $\left.I^{2}=0 \%\right)$. The MLT group had a $4.43 \%(\mathrm{n}=25 / 564)$ neurotoxicity rate, which was significantly lower than that of $16.31 \%$ $(\mathrm{n}=92 / 564)$ in the control group, with combined RR 0.30 (95\% CI, 0.19-0.45; $P<0.00001$ ).

\section{Thrombocytopenia}

A total of seven studies were involved with the incidence of thrombocytopenia in cancer patients during chemotherapy or radiotherapy. There was no heterogeneity between the results of these studies ( $P=0.61, I^{2}=0 \%$ ), and a fixed model was used to analyze the results as the following Figure 8. There are 1,230 cancer patients in the MLT group, of whom
37 patients happened to thrombocytopenia during treatment. And, the overall thrombocytopenia rate in the MLT and control groups was 3.01 and $13.20 \%$, respectively. MLT can significantly reduce the incidence of thrombocytopenia in patients with cancer during treatment $(\mathrm{RR}=0.23 ; 95 \% \mathrm{CI}$, $0.16-0.33 ; P<0.00001)$.

\section{Asthenia}

There were nine RCTs recording the incidence of asthenia, with a total of 2,658 cancer patients as shown in Figure 9. There was no heterogeneity between the results $\left(P=0.44, I^{2}=0 \%\right)$, and a fixed model was performed to analyze the results. The incidence of asthenia was $18.91 \%(n=251 / 1,327)$ in the MLT group and $43.50 \%(n=579 / 1,331)$ in the control group. Moreover, the combined RR was 0.43 (95\% CI, 0.38-0.49; $P<0.00001)$, revealing that MLT could reduce the occurrence of asthenia.

\section{Publication bias}

The publication bias was analyzed by funnel plot as shown in Figure 10. There is a suggestion of publication bias evident in the funnel plot (Harbord test: $t=2.2794$, $\mathrm{df}=14$, $P$-value $=0.03883$ ), as there were many studies came from the same research center.

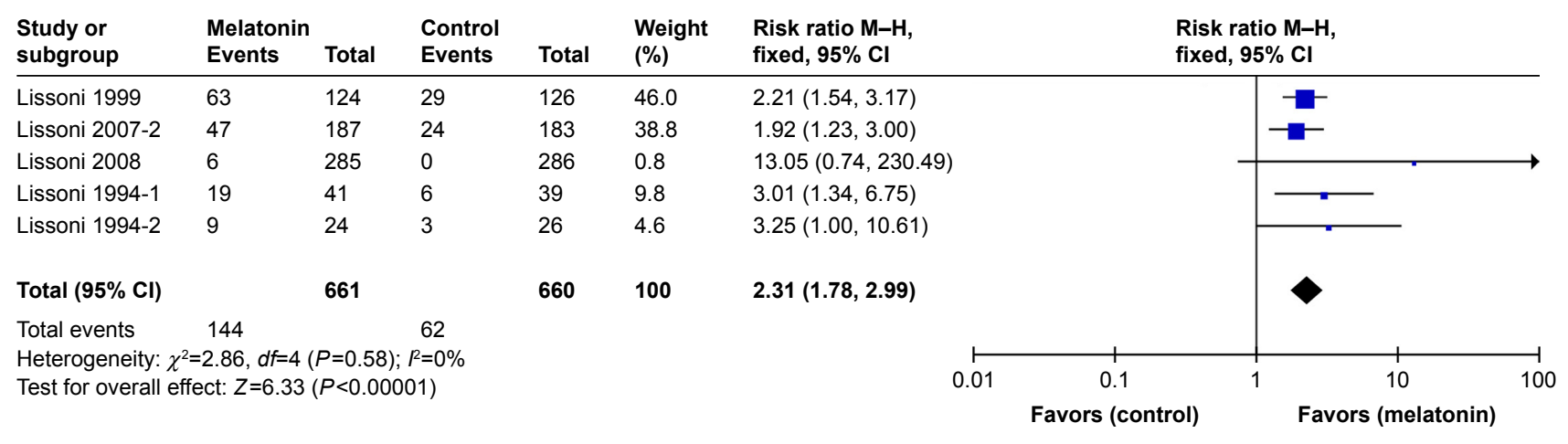

Figure 5 Meta-analysis of the overall survival rate of multiple solid cancers treated with MLT. Abbreviations: MLT, melatonin; M-H, Mantel-Haenszel. 


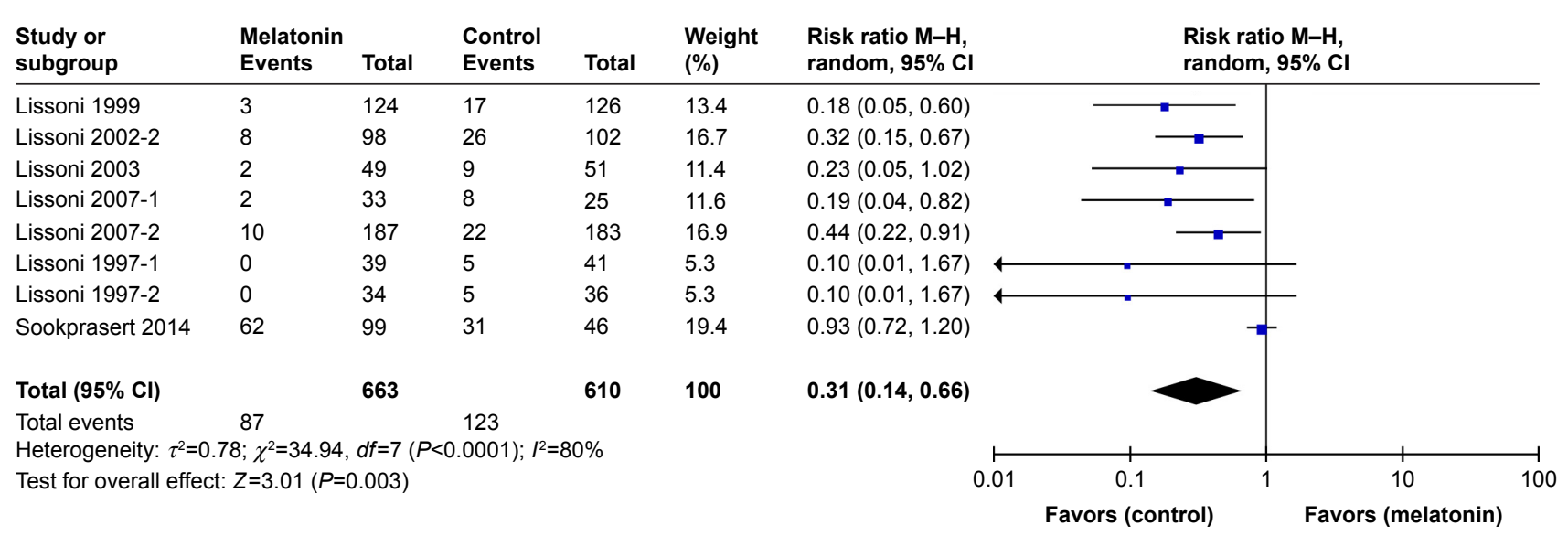

Figure 6 Meta-analysis of the neurotoxicity rate of cancer treated with MLT during chemotherapy. Abbreviations: MLT, melatonin; M-H, Mantel-Haenszel.

\section{Discussion}

In our study, a systematic review of the clinical effects of MLT in the treatment of tumors has been summarized. Although several studies have reviewed the effects of MLT in cancer therapy, its assessment of MLT remains inconsistent. Kubatka et al ${ }^{31}$ studied the impact of MLT on breast cancer and its mechanism of anticancer effect from preclinical and clinical studies. Kubatka et $\mathrm{al}^{31}$ also affirmed the efficiency of MLT or MLT combined with chemotherapy in the treatment of early breast cancer. Reiter et al, ${ }^{10}$ Yasueda et al, ${ }^{32}$ and Sanchez-Barcelo et $\mathrm{al}^{21}$ systematically summarized the clinical studies of MLT in the treatment of cancer to confirm the efficacy of MLT in the treatment of tumor and their role in reducing the side effects of chemotherapy. Although MLT possessed excellent antioxidant properties to scavenge ROS, whether taking or avoiding antioxidants during chemotherapy remained a mystery for complexed oxidation status. For example, promotion of cancer cells was attributed to a drop in intracellular oxygen, but further accumulation of active
ROS would lead to tumor cell apotosis. ${ }^{33}$ The mechanisms of MLT exerting antitumor effect might involve with other pathways, such as antiangiogenesis and pro-oxidant. According to a recent review, MLT could overcome drug resistance in cancer chemotherapy through the following ways: ${ }^{22}$ 1) MLT would increase response to treatment via modulating the expression and phosphorylation status of drug targets; 2) MLT was able to reduce the clearance of chemotherapeutics by affecting their metabolism and transport; 3) MLT had ability to decrease the survival of malignant cells via altering DNA; 4) MLT could enhance responsiveness to cell deathassociated mechanisms such as apoptosis and autophagy.

Further in our meta-analysis, we collected 20 RCTs about the efficacy of MLT in tumor therapy and summarized the data. We found that the study spanned from 1992 to 2014 and concentrated from 1994 to 2002. It was involved multiple tumors (13 lung cancer studies, 11 digestive system tumor studies, seven breast cancer studies, two prostate cancer studies, two kidney cancer studies, one head and neck

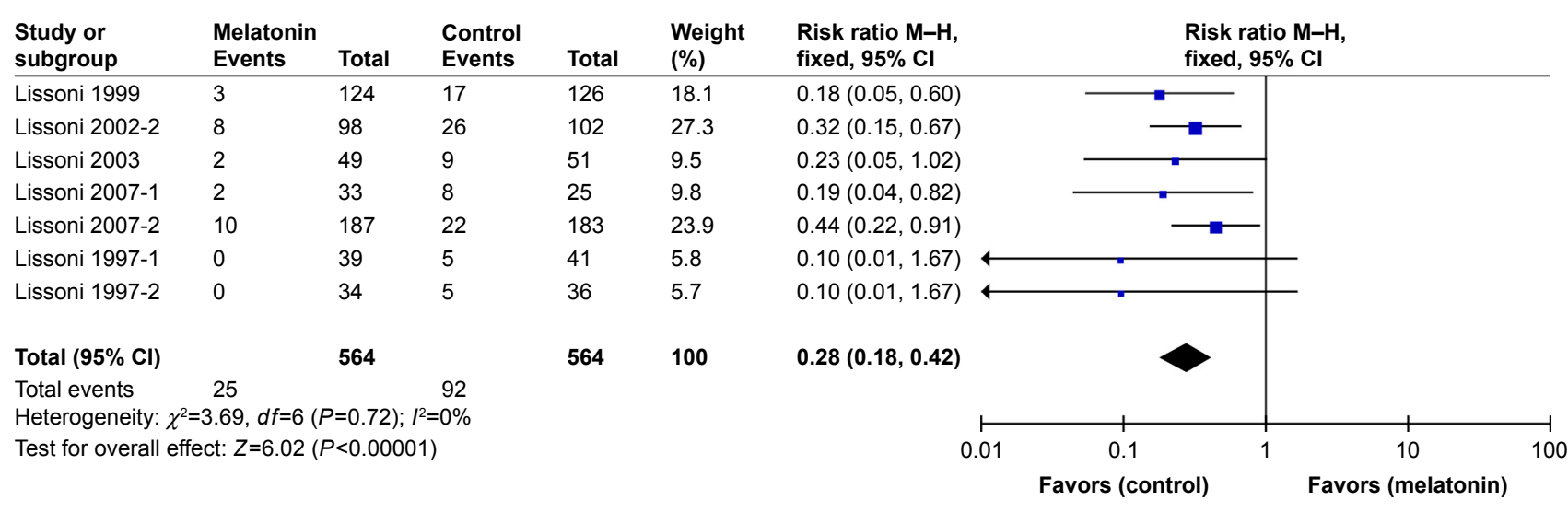

Figure 7 Meta-analysis of the neurotoxicity rate of cancer treated with MLT during chemotherapy after sensitivity analysis (removing the study of Sookprasert 20I4). Abbreviations: MLT, melatonin; M-H, Mantel-Haenszel. 


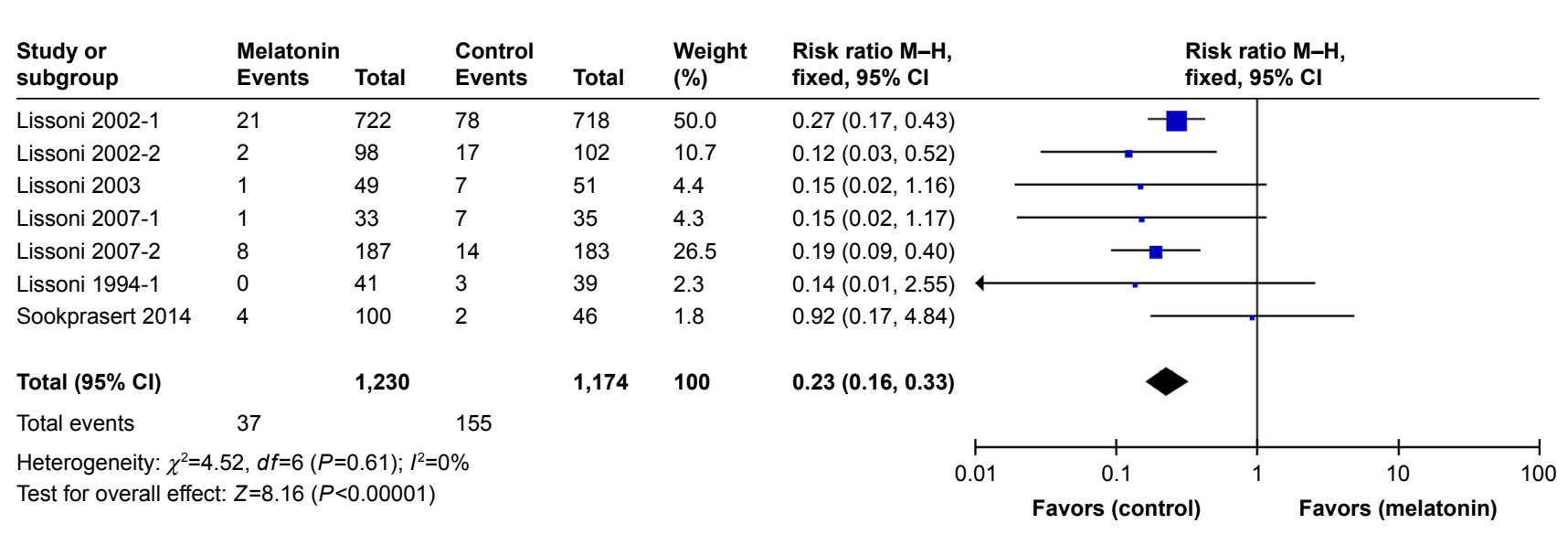

Figure 8 Meta-analysis of the thrombocytopenia rate of cancer treated with MLT during chemotherapy. Abbreviations: MLT, melatonin; M-H, Mantel-Haenszel.

cancer study, one glioma study, and two melanoma studies). The interventions were MLT combined with chemotherapy or other treatments as experimental group and chemotherapy or other treatments as control group. Among them, the dosage and the way of taking MLT are mostly $20 \mathrm{mg} /$ day and taken orally and taken at night, respectively. The MLT dosage was $10 \mathrm{mg} /$ day in the study of Lissoni et al. ${ }^{34}$ The indicators for the study were the disease response rate $(C R+P R)$, survival rate, and the incidence of side effects of chemotherapy and radiotherapy. Through the combination of the results of the study, it was demonstrated that MLT significantly decreased the tumor remission rate compared to the control group (RR $=2.25 ; 95 \% \mathrm{CI}, 1.86-2.71 ; P<0.00001)$. In the survival rate study, 15 studies results were found to be heterogeneous $\left(P=0.006, I^{2}=55 \%\right)$. Therefore, randomized models were applied to pool the results and the combined MLT survival rate was $28.24 \%(n=294 / 1,041)$. Compared with the control group, the survival rate of cancer patients in the MLT group was greatly improved $(\mathrm{RR}=2.07 ; 95 \% \mathrm{CI}, 1.55-2.76$; $P<0.00001)$. Then, we analyzed the source of heterogeneity. Sensitive analysis results did not find that a single study had an impact on the heterogeneity of the pooled study results. Stratified analysis was discussed by different tumor types, which effectively reduced the heterogeneity of the pooled study results. There were four RCTs in subjects with non-smallcell lung cancer, and no heterogeneity existed among the results $\left(P=0.55, I^{2}=0 \%\right)$. The survival rate of MLT group was $27.98 \%(n=61 / 218)$, significantly higher than that of $14.46 \%$ $(n=24 / 166)$ in the control group. And, the pooled RR was 2.13 (95\% CI, 1.41-3.24; $P=0.0004)$. There are five clinical studies about a variety of solid tumors, and no heterogeneity was found in these results $\left(P=0.58, I^{2}=0 \%\right)$. The survival rate in the MLT group is $21.79 \%(n=144 / 661)$, significantly higher than survival rate of $9.39 \%(n=62 / 660)$ in the control group.

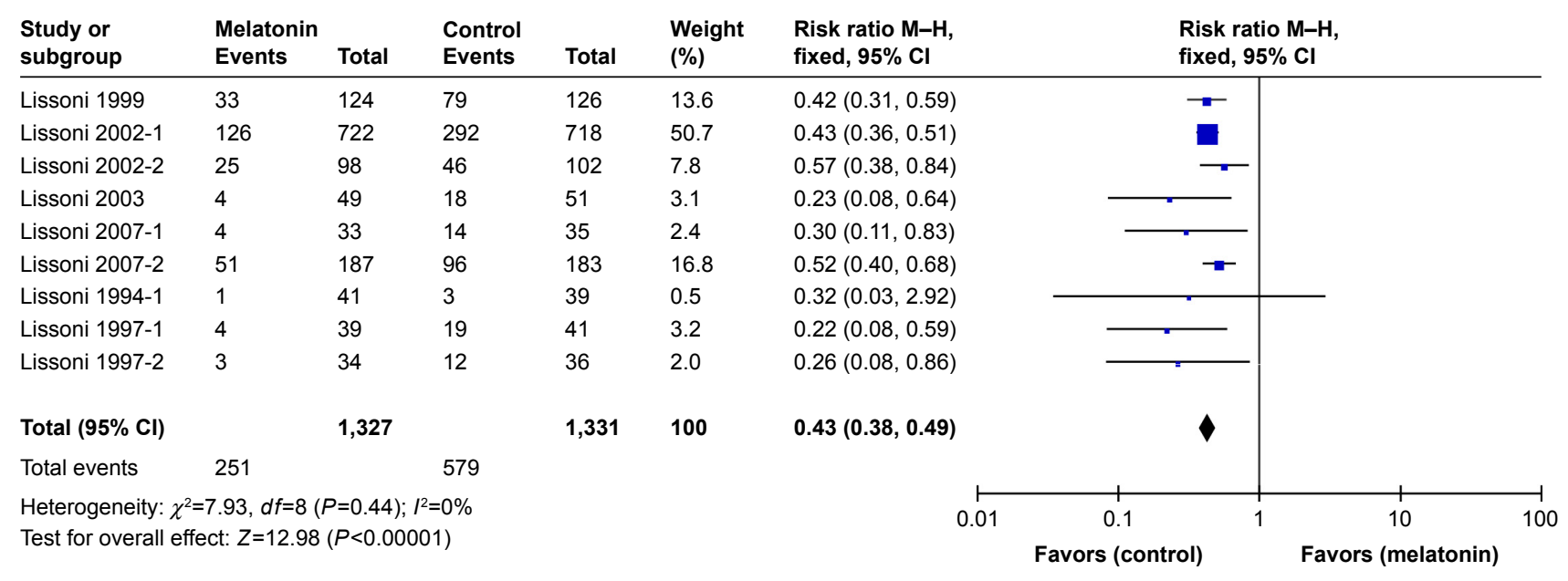

Figure 9 Meta-analysis of the asthenia rate of cancer treated with MLT during chemotherapy. Abbreviations: MLT, melatonin; M-H, Mantel-Haenszel. 


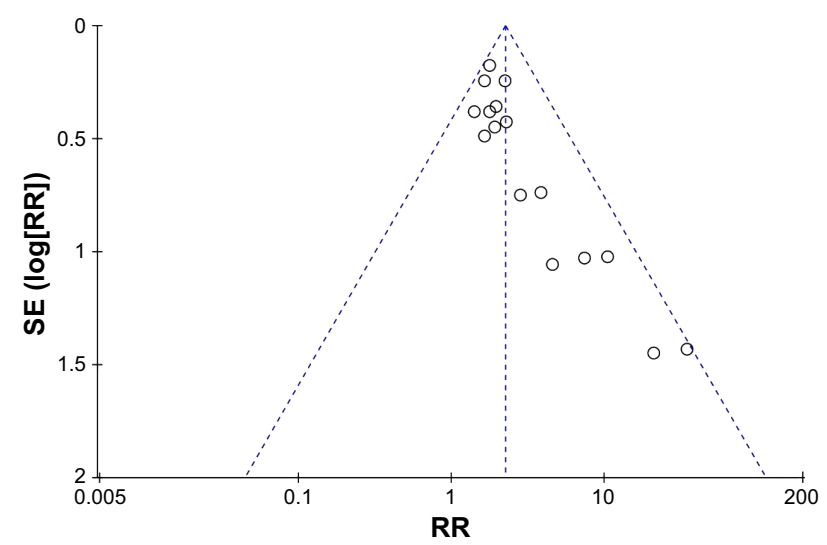

Figure 10 Funnel plot: Harbord test: $t=2.2794, \mathrm{df}=14, P$-value $=0.03883$. Abbreviation: RR, relative risk.

The combined RR was 2.31 (95\% CI, 1.78-2.99; $P<0.00001)$. When the study results were grouped by tumor type, there was no heterogeneity among the results in each subgroup, indicating that the survival rates of patients with different types of tumors were different. Therefore, in the clinical study of MLT-assisted tumor therapy, it is necessary to strictly classify the tumor types and not to sum it up. In the study of reducing side effects of chemotherapy, it was confirmed that MLT can effectively reduce the incidence rate of neurotoxicity $(\mathrm{RR}=0.30,95 \% \mathrm{CI}, 0.19-0.45 ; P<0.00001)$, thrombocytopenia $(\mathrm{RR}=0.23 ; 95 \% \mathrm{CI}, 0.16-0.33 ; P<0.00001)$, and asthenia (RR $=0.43,95 \%$ CI, 0.38-0.49; $P<0.00001)$.

\section{Conclusion}

Based on the above meta-analysis results, it was concluded that MLT, as an adjuvant for the treatment of tumors, can effectively improve the remission rate and overall survival rate of tumor patients, while reducing the incidence rate of neurotoxicity, thrombocytopenia, and asthenia during chemotherapy. However, most of the included studies were concentrated in 1994-2002 and the latest research date was 2014. In recent years, most of the subjects involved with anticancer effect of MLT were preclinical studies rather than clinical studies. And, 16 of the 20 clinical studies were completed at the same research center, which suggested certain publication bias evident. It was highly recommend that large-scale RCTs about therapeutic effects of MLT in tumors were conducted in multiple clinical research centers for further study.

\section{Disclosure}

The authors report no conflicts of interest in this work.

\section{References}

1. Tuli HS, Kashyap D, Sharma AK, Sandhu SS. Molecular aspects of melatonin (MLT)-mediated therapeutic effects. Life Sci. 2015;135:147-157.
2. Su SC, Hsieh MJ, Yang WE, Chung WH, Reiter RJ, Yang SF. Cancer metastasis: Mechanisms of inhibition by melatonin. $J$ Pineal Res. 2017;62(1):e12370.

3. Innominato PF, Lim AS, Palesh O, et al. The effect of melatonin on sleep and quality of life in patients with advanced breast cancer. Support Care Cancer. 2016;24(3):1097-1105.

4. Acuña-Castroviejo D, Rahim I, Acuña-Fernández C, et al. Melatonin, clock genes and mitochondria in sepsis. Cell Mol Life Sci. 2017;74(21): 3965-3987.

5. Schernhammer ES, Hankinson SE. Urinary melatonin levels and breast cancer risk. J Natl Cancer Inst. 2005;97(14):1084-1087.

6. Karasek M, Kowalski AJ, Suzin J, Zylinska K, Swietoslawski J. Serum melatonin circadian profiles in women suffering from cervical cancer J Pineal Res. 2005;39(1):73-76.

7. Zhao M, Wan J, Zeng K, et al. The Reduction in Circulating Melatonin Level May Contribute to the Pathogenesis of Ovarian Cancer: A Retrospective Study. J Cancer. 2016;7(7):831-836.

8. Turgut M, Uyanikgil Y, Baka M, et al. Pinealectomy exaggerates and melatonin treatment suppresses neuroma formation of transected sciatic nerve in rats: gross morphological, histological and stereological analysis. J Pineal Res. 2005;38(4):284-291.

9. Bartsch H, Buchberger A, Franz H, et al. Effect of melatonin and pineal extracts on human ovarian and mammary tumor cells in a chemosensitivity assay. Life Sci. 2000;67(24):2953-2960.

10. Reiter RJ, Rosales-Corral SA, Tan DX, et al. Melatonin, a Full Service Anti-Cancer Agent: Inhibition of Initiation, Progression and Metastasis. Int J Mol Sci. 2017;18(4):E843.

11. Asghari MH, Moloudizargari M, Ghobadi E, Fallah M, Abdollahi M Melatonin as a multifunctional anti-cancer molecule: Implications in gastric cancer. Life Sci. 2017;185:38-45.

12. González-González A, Mediavilla MD, Sánchez-Barceló EJ. Melatonin: A Molecule for Reducing Breast Cancer Risk. Molecules. 2018; 23(2):E336

13. González A, González-González A, Alonso-González C, MenéndezMenéndez J, Martínez-Campa C, Cos S. Melatonin inhibits angiogenesis in SH-SY5Y human neuroblastoma cells by downregulation of VEGF. Oncol Rep. 2017;37(4):2433-2440.

14. Zonta YR, Martinez M, Camargo IC, et al. Melatonin Reduces Angiogenesis in Serous Papillary Ovarian Carcinoma of Ethanol-Preferring Rats. Int J Mol Sci. 2017;18(4):E763.

15. González A, Alvarez-García V, Martínez-Campa C, et al. In vivo inhibition of the estrogen sulfatase enzyme and growth of DMBA-induced mammary tumors by melatonin. Curr Cancer Drug Targets. 2010; 10(3):279-286.

16. Plaimee P, Khamphio M, Weerapreeyakul N, Barusrux S, Johns NP. Immunomodulatory effect of melatonin in SK-LU-1 human lung adenocarcinoma cells co-cultured with peripheral blood mononuclear cells. Cell Prolif. 2014;47(5):406-415.

17. Kim TH, Cho SG. Melatonin-induced KiSS1 expression inhibits triple-negative breast cancer cell invasiveness. Oncol Lett. 2017;14(2): 2511-2516.

18. Akbarzadeh M, Movassaghpour AA, Ghanbari H, et al. The potential therapeutic effect of melatonin on human ovarian cancer by inhibition of invasion and migration of cancer stem cells. Sci Rep. 2017;7(1):17062.

19. Sainz RM, Mayo JC, Tan DX, León J, Manchester L, Reiter RJ. Melatonin reduces prostate cancer cell growth leading to neuroendocrine differentiation via a receptor and PKA independent mechanism. Prostate. 2005;63(1):29-43.

20. Suwanjang W, Abramov AY, Charngkaew K, Govitrapong P, Chetsawang B. Melatonin prevents cytosolic calcium overload, mitochondrial damage and cell death due to toxically high doses of dexamethasone-induced oxidative stress in human neuroblastoma SH-SY5Y cells. Neurochem Int. 2016;97:34-41.

21. Sanchez-Barcelo EJ, Mediavilla MD, Alonso-Gonzalez C, Reiter RJ. Melatonin uses in oncology: breast cancer prevention and reduction of the side effects of chemotherapy and radiation. Expert Opin Investig Drugs. 2012;21(6):819-831. 
22. Asghari MH, Ghobadi E, Moloudizargari M, Fallah M, Abdollahi M. Does the use of melatonin overcome drug resistance in cancer chemotherapy? Life Sci. 2018;196:143-155.

23. Wang T, Liu B, Guan Y, et al. Melatonin inhibits the proliferation of breast cancer cells induced by bisphenol A via targeting estrogen receptor-related pathways. Thorac Cancer. 2018;9(3):368-375.

24. Proietti S, Catizone A, Masiello MG, et al. Increase in motility and invasiveness of MCF7 cancer cells induced by nicotine is abolished by melatonin through inhibition of ERK phosphorylation. J Pineal Res. 2018;64(4):e12467.

25. Chuffa LGA, Reiter RJ, Lupi LA. Melatonin as a promising agent to treat ovarian cancer: molecular mechanisms. Carcinogenesis. 2017; 38(10):945-952.

26. Wang YM, Jin BZ, Ai F, et al. The efficacy and safety of melatonin in concurrent chemotherapy or radiotherapy for solid tumors: a metaanalysis of randomized controlled trials. Cancer Chemother Pharmacol. 2012;69(5):1213-1220.

27. Seely D, Wu P, Fritz H, et al. Melatonin as adjuvant cancer care with and without chemotherapy: a systematic review and meta-analysis of randomized trials. Integr Cancer Ther. 2012;11(4):293-303.

28. Sookprasert A, Johns NP, Phunmanee A, et al. Melatonin in patients with cancer receiving chemotherapy: a randomized, double-blind, placebo-controlled trial. Anticancer Res. 2014;34(12):7327-7337.

29. Harris JD, Quatman CE, Manring MM, Siston RA, Flanigan DC. How to write a systematic review. Am J Sports Med. 2014;42(11): 2761-2768

30. Jadad AR, Moore RA, Carroll D, et al. Assessing the quality of reports of randomized clinical trials: is blinding necessary? Control Clin Trials. 1996;17(1):1-12.

31. Kubatka P, Zubor P, Busselberg D, et al. Melatonin and breast cancer: Evidences from preclinical and human studies. Crit Rev Oncol Hematol. 2018;122:133-143.

32. Yasueda A, Urushima H, Ito T. Efficacy and Interaction of Antioxidant Supplements as Adjuvant Therapy in Cancer Treatment: A Systematic Review. Integr Cancer Ther. 2016;15(1):17-39.

33. Saeidnia S, Abdollahi M. Antioxidants: friends or foe in prevention or treatment of cancer: the debate of the century. Toxicol Appl Pharmacol. 2013;271(1):49-63.

34. Lissoni P, Barni S, Ardizzoia A, et al. Randomized study with the pineal hormone melatonin versus supportive care alone in advanced nonsmall cell lung cancer resistant to a first-line chemotherapy containing cisplatin. Oncology. 1992;49(5):336-339.

35. Lissoni P, Brivio F, Fumagalli L, et al. Neuroimmunomodulation in medical oncology: application of psychoneuroimmunology with subcutaneous low-dose IL-2 and the pineal hormone melatonin in patients with untreatable metastatic solid tumors. Anticancer Res. 2008; 28(2B):1377-1381

36. Lissoni P. Biochemotherapy with immunomodulating pineal hormones other than melatonin: 5-methoxytryptamine as a new oncostatic pineal agent. Pathol Biol (Paris). 2007;55(3-4):198-200.

37. Lissoni P. Biochemotherapy with standard chemotherapies plus the pineal hormone melatonin in the treatment of advanced solid neoplasms. Pathol Biol. 2007;55(3-4):201-204.

38. Lissoni P, Chilelli M, Villa S, Cerizza L, Tancini G. Five years survival in metastatic non-small cell lung cancer patients treated with chemotherapy alone or chemotherapy and melatonin: a randomized trial. J Pineal Res. 2003;35(1):12-15.

OncoTargets and Therapy

\section{Publish your work in this journal}

OncoTargets and Therapy is an international, peer-reviewed, open access journal focusing on the pathological basis of all cancers, potential targets for therapy and treatment protocols employed to improve the management of cancer patients. The journal also focuses on the impact of management programs and new therapeutic agents and protocols on
39. Cerea G, Vaghi M, Ardizzoia A, et al. Biomodulation of cancer chemotherapy for metastatic colorectal cancer: a randomized study of weekly low-dose irinotecan alone versus irinotecan plus the oncostatic pineal hormone melatonin in metastatic colorectal cancer patients progressing on 5-fluorouracil-containing combinations. Anticancer Res. 2003;23(2C):1951-1954.

40. Lissoni P. Is there a role for melatonin in supportive care? Support Care Cancer. 2002;10(2):110-116.

41. Yan JJ, Song F, Wang K, Wu MC. Co-antitumor effect and hepatic protection of melatonin on advanced primary liver cancer treated by tran-scatheter arterial chemoembolization. Acad J Sec Mil Med Univ. 2001;22(9):858-861.

42. Lissoni $\mathrm{P}$, Mandalà $\mathrm{M}$, Brivio $\mathrm{F}$. Abrogation of the negative influence of opioids on IL-2 immunotherapy of renal cell cancer by melatonin. Eur Urol. 2000;38(1):115-118.

43. Lissoni $\mathrm{P}$, Barni $\mathrm{S}$, Mandalà $\mathrm{M}$, et al. Decreased toxicity and increased efficacy of cancer chemotherapy using the pineal hormone melatonin in metastatic solid tumour patients with poor clinical status. Eur J Cancer. 1999;35(12):1688-1692.

44. Lissoni P, Tancini G, Barni S, et al. Treatment of cancer chemotherapyinduced toxicity with the pineal hormone melatonin. Support Care Cancer. 1997;5(2):126-129.

45. Lissoni P, Paolorossi F, Ardizzoia A, et al. A randomized study of chemotherapy with cisplatin plus etoposide versus chemoendocrine therapy with cisplatin, etoposide and the pineal hormone melatonin as a first-line treatment of advanced non-small cell lung cancer patients in a poor clinical state. J Pineal Res. 1997;23(1):15-19.

46. Yan JJ, Song F, Wu MC. Pineal hormone melatonin for treating patients with unresectable advanced hepatocellular cancer. TUMOR (Shanghai). 1997;17(6):452-454.

47. Lissoni P, Meregalli S, Nosetto L, et al. Increased survival time in brain glioblastomas by a radioneuroendocrine strategy with radiotherapy plus melatonin compared to radiotherapy alone. Oncology. 1996; 53(1):43-46.

48. Lissoni P, Brivio O, Brivio F, et al. Adjuvant therapy with the pineal hormone melatonin in patients with lymph node relapse due to malignant melanoma. J Pineal Res. 1996;21(4):239-242.

49. Lissoni P, Ardizzoia A, Barni S, et al. A randomized study of tamoxifen alone versus tamoxifen plus melatonin in estrogen receptor-negative heavily pretreated metastatic breast-cancer patients. Oncol Rep. 1995; 2(5):871-873.

50. Lissoni P, Barni S, Tancini G, et al. A randomised study with subcutaneous low-dose interleukin 2 alone vs interleukin 2 plus the pineal neurohormone melatonin in advanced solid neoplasms other than renal cancer and melanoma. Br J Cancer. 1994;69(1):196-199.

51. Lissoni P, Barni S, Ardizzoia A, Tancini G, Conti A, Maestroni G. A randomized study with the pineal hormone melatonin versus supportive care alone in patients with brain metastases due to solid neoplasms. Cancer. 1994;73(3):699-701.

52. Vernieri C, Nichetti F, Raimondi A, et al. Diet and supplements in cancer prevention and treatment: Clinical evidences and future perspectives. Crit Rev Oncol Hematol. 2018;123:57-73.

\section{Dovepress}

patient perspectives such as quality of life, adherence and satisfaction The manuscript management system is completely online and includes a very quick and fair peer-review system, which is all easy to use. Visit http://www.dovepress.com/testimonials.php to read real quotes from published authors. 